\title{
DUX4L2 wt Allele
}

National Cancer Institute

\section{Source}

National Cancer Institute. DUX4L2 wt Allele. NCI Thesaurus. Code C147932.

Human DUX4L2 gene is located in the vicinity of 4q35.2 and is approximately $1 \mathrm{~kb}$ in length. This allele, which encodes double homeobox protein 4-like protein 2, may play a role in transcription. This gene is within a D4Z4 repeat array; contraction of this macrosatellite repeat is associated with facioscapulohumeral muscular dystrophy (FSHD). 